\title{
Emasculated Trailing Blackberry Flowers Set Some Drupelets When Not Protected from Cross Pollination
}

\author{
Chad E. Finn ${ }^{1}$ \\ Corvallis, OR 97330 \\ Additional index words. blackberry breeding, Rubus sp.
}

U.S. Department of Agriculture, Agricultural Research Service, Northwest Center for Small Fruit Research, Horticultural Crops Research Laboratory,

Several steps are required for making a controlled cross in a blackberry (Rubus $\mathrm{sp}$.) breeding program. A fruiting lateral is selected that may have one primary flower open and the remainder fully developed, but with petals not yet separated. The open flower(s) and immature flowers are removed and the remaining flowers are emasculated (Hall, 1990; Ourecky, 1975). A white waxed paper bag is placed over the emasculated lateral and secured at the base with clips. The bag is further secured with clips to other laterals or the trellis wire to decrease the amount of lateral breakage due to wind or mechanical injury. Two to three days later, the bags are removed, the emasculated flowers pollinated, and the bags are securely replaced on the lateral. This pollination procedure is repeated until the stigmas are no longer receptive. Typically, a flower will be pollinated at least twice and up to five times.

Bagging emasculated flowers prevents cross pollination with unknown pollen via wind or insects and keeps the flowers dry during inclement weather. Bagging, removing bags, and rebagging the emasculated flowering laterals are time-consuming procedures when a large number of crosses is being attempted, and can lead to damage of flowers or the laterals. In addition, the increased rigid surface area the bag provides when compared to an unbagged lateral can lead to the laterals breaking off in the wind, even when the bags are well-secured to other laterals or the trellis system. The flowers or developing fruit are then lost.

In some fruit breeding programs flowers are not bagged after emasculation (Brown, 1975). Since blackberries are insect-pollinated, little or no pollination should take place when the petals and anthers are removed. Eliminat-

Received for publication 19 Jan. 1996. Accepted for publication 8 May 1996. The cost of publishing this paper was defrayed in part by the payment of page charges. Under postal regulations, this paper therefore must be hereby marked advertisement solely to indicate this fact.

${ }^{1}$ Research Geneticist. ing bagging in our blackberry breeding program was appealing. The objective of this study was to determine whether emasculated trailing blackberry flowers set drupelets when they were not protected from cross pollination by bagging.

'Marion' and three advanced selections (ORUS 830-4, ORUS 913-10, ORUS 1111-1) from the U.S. Dept. of Agriculture-Agricultural Research Service (Corvallis, Ore.) trailing blackberry breeding program were used in this study. The plants were growing at Oregon State Univ.'s Lewis-Brown Farm (Corvallis). Each clone was represented by three to eight plants trained to a two-wire trellis (lower wire at $75 \mathrm{~cm}$, upper wire $150 \mathrm{~cm}$ ). The plants appeared to be healthy without disease or winter injury symptoms.

On 18 May 1994, six flowering laterals were selected from each genotype, three from each side of the row. The laterals also were selected from a range of heights on the trellised canopy, from above the top wire to the lower wire. Flowers within $10 \mathrm{~cm}$ of the lateral to be emasculated were removed. Any open flowers on the lateral also were removed. Each lateral had four to seven flowers that were fully developed and the petals had not yet begun to separate. These flowers were emasculated but not bagged or manually pollinated.

As the fruit for each genotype began to color, the entire lateral was harvested. An adjacent lateral with the same number of fruit that had not been emasculated also was harvested as a control. The control laterals had fruit in similar positions as on the emasculated laterals so that primary fruit were compared to primary fruit, secondary to secondary, and tertiary to tertiary. The number of drupelets that developed was recorded for each fruit. An analysis of variance was conducted on the number of drupelets for fruit from emasculated flowers and controls as well as the difference between these two numbers.

When the emasculated fruit did set drupelets, the number of drupelets per fruit was low (Table 1). Therefore, the averages are not the result of one fruit having a full complement of drupelets and the rest having very few drupelets. While drupelet count varied among genotypes on the control flowers, the number did not vary for those emasculated. The differences in set between control and emasculated flowers were nonuniform among genotypes (Table 1).

Drupelet count for emasculated flowers as a percentage of the control ranged from $0.2 \%$ for 'Marion' to $8.2 \%$ for ORUS 913-10. Whether this range would be an acceptable level of contamination is an individual breeding program's decision. The range may be acceptable if the crosses are designed with the sole purpose of producing improved cultivars. However, for inheritance studies, where control of the crosses is critical, it would not be acceptable.

The set drupelets on the emasculated flowers are probably a result of pollen falling from an unemasculated flower or the pollen may have been vectored by the wind or insects. However, they may be due to selfing during emasculation or apomixis. Apomixis is common in some blackberry species (e.g., $R$. armeniacus Focke). A treatment that consisted of bagged emasculated flowers might have identified whether apomixis was occurring in these genotypes. While this was not done as part of this study, we regularly emasculate and bag extra flowering laterals of 'Marion', 'Kotata', and 'Waldo' and see no drupelet set.

\section{Literature Cited}

Brown, A.G. 1975. Apples, p. 3-37. In: J. Janick and J.N. Moore (eds.). Advances in fruit breeding. Purdue Univ. Press, West Lafayette, Ind.

Hall, H.K. 1990. Blackberry breeding, p. 249-312. In. J. Janick (ed.). Plant breeding reviews. vol. 8. Timber Press, Portland, Ore.

Ourecky, D.K. 1975. Brambles, p. 98-129. In: J. Janick and J.N. Moore (eds.). Advances in fruit breeding. Purdue Univ. Press, West Lafayette, Ind.

Table 1. Average number of drupelets set per blackberry fruit from flowers that were not protected from cross pollination and that were either emasculated or left as unemasculated controls.

\begin{tabular}{lccc}
\hline \hline $\begin{array}{l}\text { Cultivar/ } \\
\text { selection }\end{array}$ & \multicolumn{2}{c}{ Drupelets/fruit (mean no.) } & \multirow{2}{*}{$\begin{array}{c}\text { Drupelet set on } \\
\text { emasculated flowers }(\%)^{2}\end{array}$} \\
\cline { 2 - 3 } Marion & Emasculated flowers & Control & \\
ORUS 830-4 & 0.1 & 65.9 & 0.2 \\
ORUS 913-10 & 3.1 & 90.0 & 3.4 \\
ORUS 1111-1 & 4.3 & 52.7 & 8.2 \\
LSD $_{(0.05)}$ & 4.6 & 99.7 & 4.6 \\
\hline
\end{tabular}

${ }^{2}$ Number of drupelets for emasculated flowers/number of drupelets for control. 